\title{
Originals
}

\section{Insulin Production Rate, Hepatic Insulin Retention and Splanchnic Carbohydrate Metabolism After Oral Glucose Ingestion in Hyperinsulinaemic Type 2 (Non-Insulin-Dependent) Diabetes Mellitus}

\author{
W. Waldhäusl, P. Bratusch-Marrain, S. Gasić, A. Korn and P. Nowotny \\ I. Medizinische Universitätsklinik, Division of Clinical Endocrinology and Diabetes Mellitus, Wien, Austria
}

Summary. To differentiate peripheral and hepatic insulin resistance in hyperinsulinaemic overweight Type 2 (non-insulindependent) diabetic patients ( $n=17 ; 143 \pm 4 \%$ ideal body weight; mean \pm SEM) arterial concentrations and splanchnic exchange of glucose, pyruvate, lactate, non-esterified fatty acids, $\beta$-hydroxybutyrate and acetoacetate, as well as the insulin production rate, were determined before and during oral glucose loads of $25 \mathrm{~g}$ or $100 \mathrm{~g}$. Insulin production rate, hepatic insulin retention and splanchnic exchange of glucose and metabolites were estimated by means of the hepatic venous catheter technique. In the basal state insulin production rate was greater in overweight Type 2 diabetic patients $\left(2.57 \pm 0.28\right.$ pmol. $\mathrm{kg}^{-1}$. $\left.\min ^{-1}\right)$ than in healthy control subjects $(1.68 \pm 0.17$ pmol.kg ${ }^{-1} \cdot \min ^{-1} ; p<0.01$ ). After ingestion of 25 g glucose, the cumulative insulin production rate exceeded normal values $(p<0.05)$, but was below normal with $100 \mathrm{~g}$ glucose $(p<0.01)$. Relative insulin trapping by the splanchnic bed in the diabetic patients was $54 \pm 3 \%$, not different from normal. Following a $100 \mathrm{~g}$ glucose load, splanchnic insulin retention fell by $20 \%$ in the patients, and less consistently so in healthy controls.
Splanchnic glucose output was normal in the diabetic patients both in the basal state and after glucose ingestion although the induced arterial blood glucose levels were greater in the diabetic patients than in control subjects $(p<0.005)$. Splanchnic output of pyruvate $(p<0.025)$, lactate $(p<0.01)$, and $\beta$-hydroxybutyrate $(p<0.005)$ were greater in the basal state in the diabetic patients than in healthy subjects. However, no difference in splanchnic exchange was seen between the two groups in their metabolites' respective response to glucose ingestion. These data suggest that obese hyperinsulinaemic Type 2 diabetic patients may represent a subgroup of diabetic patients with predominantly peripheral, but compensated hepatic, insulin resistance being associated with an increased basal insulin production rate which only exhausts after ingestion of a large glucose load.

Key words: Obesity, Type 2 diabetes, hyperinsulinaemia, insulin production rate, splanchnic insulin retention, splanchnic glucose output, insulin resistance.
Type 2 (non-insulin-dependent) diabetes mellitus is associated with a variety of abnormalities in insulin release and actions, as well as in carbohydrate metabolism. Both insulin deficiency $[1,2]$ and augmented insulin secretion [3-5] have been described. Fajans et al. [6] have divided patients with comparable degrees of glucose intolerance into 'low' and 'high' insulin responders. Furthermore, reduced sensitivity of peripheral tissue to insulin $[7,8]$, and impaired ${ }^{125}$ I-insulin binding to monocytes [9] have been well documented. Some of these observations reviewed recently [10] confirm the hypothesis already advocated by Himsworth [11] that insulin insensitivity and not insulin deficiency is present in many such patients.

To determine the net rate of hepatic glucose exchange and systemic glucose turnover in diabetic patients, the hepatic venous catheter technique $[12,13]$ and isotope dilution methods $[14,15]$ have been used. It was concluded that in Type 2 diabetes net splanchnic glucose output is normal in the basal state [12], but increased above normal after an oral glucose load, and that impaired splanchnic glucose retention is a major cause of post-prandial hyperglycaemia in normal weight maturity-onset Type 2 diabetic patients [13]. Whether this impairment of hepatic glucose disposal is due to a reduced insulin production rate, impaired insulin extraction by the liver or hepatic insulin resistance remains to be elucidated, since little is known of the interrelationship between insulin production rate and glucose metabolism in Type 2 diabetes. Direct measurement of insulin secretion is not feasible in man: this problem has recently been overcome by calculating the pancreatic insulin production rate from the difference in hepatic venous and arterial immuno-reactive $\mathrm{C}$-peptide concentrations multiplied by the estimated hepatic plasma flow [16]. 
Table 1. Clinical data of 17 patients with Type 2 diabetes with serum C-peptide concentrations before and after IV arginine ( $30 \mathrm{~g}$ )

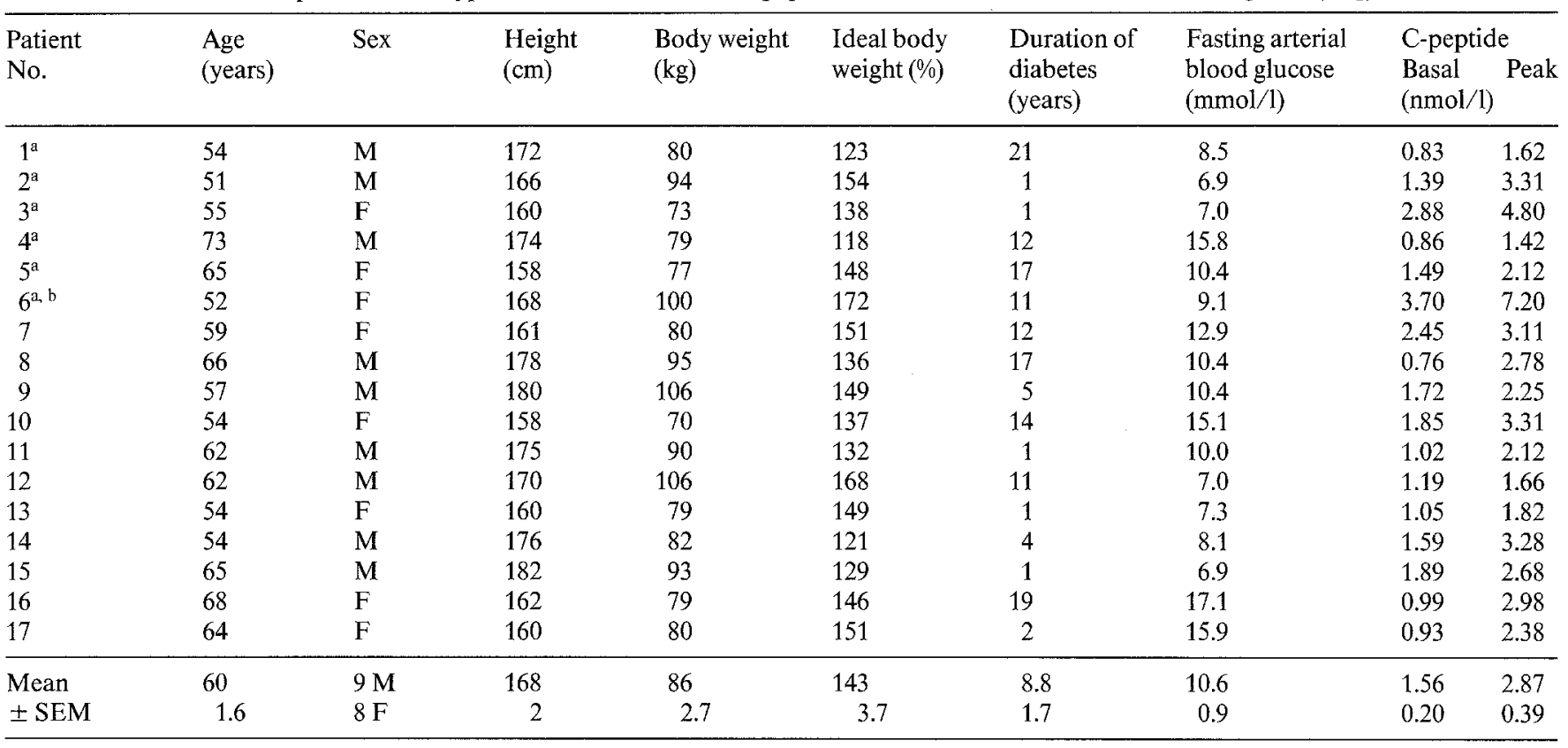

${ }^{a}$ Patients who participated in the studies using a $25 \mathrm{~g}$ glucose load

${ }^{b}$ Only basal data included for calculations as vomiting occurred following glucose ingestion

This study was consequently designed firstly to examine whether the interdependence of insulin production rate and splanchnic glucose and substrate metabolism differs in overweight Type 2 diabetic patients with basal hyperinsulinaemia from that reported previously for healthy subjects $[16,17]$; and also to determine the extent to which insulin is retained by the splanchnic bed in the basal state and following glucose ingestion in these groups. To this end the hepatic venous catheter technique was used.

\section{Methods}

\section{Subjects}

Subjects were 17 Type 2 diabetic patients (ten males and seven females) aged between 51 and 73 years. Clinical data are given in Table 1 . The patients had a history of fasting hyperglycaemia (blood glucose $>$ $8 \mathrm{mmol} / \mathrm{l})$ and glycosuria ( $>10 \mathrm{~g} / 24 \mathrm{~h}$ ) on multiple occasions in the untreated state, and were well controlled when on oral glibenclamide. The patients had not taken any drugs for at least one week preceding the study, and had never received exogenous insulin. All were overweight ( $143 \pm 4 \%$ of ideal body weight as determined by Metropolitan Life Insurance Tables, 1959). There was no evidence of liver disease as indicated by normal liver function tests. Duration of diabetes was 1-21 years. The patients had been selected on the basis of fasting hyperglycaemia while off medication. Testing for insulin secretory capacity by means of an IV arginine infusion ( $30 \mathrm{~g}$ for $30 \mathrm{~min}$ ) revealed a normal or supranormal rise in plasma C-peptide concentration (maximal increment $1.31 \pm 0.19 \mathrm{nmol} / 1)$. The respective basal and peak levels of peripheral venous serum C-peptide concentrations in healthy subjects $(n=11)$ were $0.66 \pm 0.04 \mathrm{nmol} / 1$ before and $1.7 \pm 0.16 \mathrm{nmol} / 1$ after arginine infusion. For at least 3 days before the study a controlled diet rich in carbohydrate $(>150 \mathrm{~g}$ ) was ingested by all patients.

As we were unable to recruit any age-matched obese subjects with normal glucose tolerance, the control group consisted of ten healthy non-obese male volunteers, who were within $10 \%$ of ideal body weight and between 19 and 29 years of age. They underwent the same protocol as described for the diabetic patients. In addition, data on another eight healthy subjects were included for the calculation of basal splanchnic exchange and of the regression and 95\% prediction interval for the correlation of splanchnic glucose retention and total splanchnic Cpeptide output. These subjects were between the age of 19 and 36 years and have been described in detail in previous reports from this laboratory $[16,17]$. The nature, purpose and possible risks involved in the study were carefully explained to all patients and healthy subjects before obtaining their voluntary, written consent to participate. The study was approved by the Ethical Committee of the Hospital.

\section{Procedures}

The studies were performed in the morning after an overnight fast with subjects in the recumbent position. Catheters were inserted percutaneously into a peripheral vein, a femoral artery and through a femoral vein into a right sided hepatic vein under fluoroscopic control $[18,19]$. The tip of the catheter was placed $4-5 \mathrm{~cm}$ from the wedge position When the catheters were in place arterial and hepatic venous blood was drawn simultaneously (within $30 \mathrm{~s}$ ) at $7.5 \mathrm{~min}$ intervals for a $30 \mathrm{~min}$ basal control period and for $150 \mathrm{~min}$ after oral glucose administration. Oral glucose (glucose monohydrate $55 \mathrm{~g} / 130 \mathrm{ml}$ corresponding to $50 \mathrm{~g}$ glucose, Boehringer-Mannheim, Mannheim, FRG) was ingested over 2-3 min in doses of $25 \mathrm{~g}$ (diabetic patients, $n=6$; healthy subjects, $n=5$ ) and $100 \mathrm{~g}$ (diabetic patients, $n=11$; healthy subjects, $n=5$ ).

Glucose was analyzed in whole blood using the hexokinase reaction [20]. Pyruvate, lactate, acetoacetate and $\beta$-hydroxybutyrate were determined enzymatically in plasma [21]. Plasma insulin [IRI, 22] and C-peptide (Byk-Mallinckrodt, Dietzenbach, FRG) were measured by radioimmunoassay.

Estimation of hepatic blood flow and plasma flow by means of the hepatic venous catheter technique using a constant infusion of indocyanine green dye [23] has been described previously [18]. Splanchnic exchange of glucose, metabolites and hormones was calculated from the trans-splanchnic (hepatic venous - arterial) concentration difference multiplied by the estimated hepatic blood or plasma flow, as appropriate, and expressed per kg body weight; a positive splanchnic balance indicates a net output, a negative one net splanchnic uptake. Total output from the splanchnic bed for all variables during the $150 \mathrm{~min}$ follow- 
Table 2. Basal concentrations of blood glucose, plamsa IRI, C-peptide and metabolites in arterial blood and hepatic venous effluent as well as their net splanchnic output in 17 Type 2 diabetic patients

\begin{tabular}{|c|c|c|c|c|c|c|}
\hline \multirow[b]{2}{*}{ Estimated hepatic blood flow $(\mathrm{ml} / \mathrm{min})$} & \multicolumn{6}{|c|}{ Time (min) } \\
\hline & 1,468 & \pm 96 & 1,387 & \pm 79 & 1,311 & \pm 87 \\
\hline \multicolumn{7}{|l|}{ Blood glucose $(\mathrm{mmol} / \mathrm{l})$} \\
\hline Arterial & $10.4=$ & $\pm \quad 0.9$ & $10.3 \pm$ & $\pm \quad 0.9$ & $10.3=$ & $\pm \quad 0.9$ \\
\hline Hepatic venous & $10.9=$ & $\pm \quad 0.9$ & $10.9 \pm$ & $\pm \quad 0.9$ & $10.8=$ & $\pm \quad 0.9$ \\
\hline Splanchnic glucose output $\left(\mathrm{mg} \cdot \mathrm{kg}^{-1} \cdot \mathrm{min}^{-1}\right)$ & $1.68 \pm$ & $\pm \quad 0.20$ & $1.84 \pm$ & $\pm \quad 0.23$ & 1.80 & $\pm \quad 0.18$ \\
\hline \multicolumn{7}{|l|}{ IRI (pmol/1) } \\
\hline Arterial & 157 & \pm 48 & 144 & \pm 38 & 176 & \pm 63 \\
\hline Hepatic venous & 276 & \pm 113 & 237 & \pm 60 & 261 & \pm 95 \\
\hline Hepatic venous - arterial & 119 & \pm 65 & 92 & \pm 24 & 85 & \pm 32 \\
\hline Splanchnic IRI output ${ }^{\mathrm{a}}\left(\mathrm{pmol} \cdot \mathrm{kg}^{-1} \cdot \min ^{-1}\right)$ & 0.55 & $\pm \quad 0.09$ & $0.67 \pm$ & \pm 0.11 & $0.51=$ & $\pm \quad 0.10$ \\
\hline Splanchnic C-peptide output ${ }^{\mathrm{a}}\left(\mathrm{pmol} \cdot \mathrm{kg}^{-1} \cdot \mathrm{min}^{-1}\right)$ & $2.58 \pm$ & $\pm \quad 0.40$ & $2.85 \pm$ & $\pm \quad 0.37$ & $2.38=$ & $\pm \quad 0.32$ \\
\hline Insulin production rate $\left(\mathrm{mU} \cdot \mathrm{kg}^{-1} \cdot \min ^{-1}\right)$ & $0.35 \pm$ & $\pm \quad 0.05$ & $0.39 \pm$ & \pm 0.05 & $0.33=$ & $\pm \quad 0.04$ \\
\hline \multicolumn{7}{|l|}{ Pyruvate $(\mu \mathrm{mol} / 1)$} \\
\hline Arterial & 129 & \pm 20 & 133 & \pm 20 & 130 & \pm 20 \\
\hline Hepatic venous & 117 & \pm 21 & 119 & \pm 21 & 121 & \pm 22 \\
\hline Hepatic venous - arterial & -13 & \pm 6 & -14 & \pm 8 & -9 & \pm 5 \\
\hline Splanchnic pyruvate output ${ }^{\mathrm{a}}\left(\mu \mathrm{mol} \cdot \mathrm{kg}^{-1} \cdot \min ^{-1}\right)$ & $-0.130=$ & \pm 0.061 & $-0.148 \pm$ & \pm 0.081 & -0.153 & $\pm \quad 0.072$ \\
\hline \multicolumn{7}{|l|}{ Lactate $(\mu \mathrm{mol} / 1)$} \\
\hline Arterial & 620 & \pm 47 & 567 & \pm 41 & 568 & \pm 35 \\
\hline Hepatic venous & 402 & \pm 45 & 388 & \pm 36 & 389 & \pm 40 \\
\hline Hepatic venous - arterial & -217 & \pm 18 & -179 & \pm 15 & -179 & \pm 20 \\
\hline \multicolumn{7}{|l|}{$\beta$-hydroxybutyrate $(\mu \mathrm{mol} / \mathrm{l})$} \\
\hline Arterial & 558 & \pm 67 & 550 & \pm 64 & 543 & \\
\hline Hepatic venous & 646 & \pm 73 & 632 & \pm 67 & 647 & \pm 70 \\
\hline Hepatic venous - arterial & & \pm 18 & 62 & \pm 14 & 85 & \pm 19 \\
\hline Splanchnic $\beta$-hydroxybutyrate output $\mathrm{t}^{\mathrm{a}}\left(\mu \mathrm{mol} \cdot \mathrm{kg}^{-1} \cdot \min ^{-1}\right)$ & $0.557=$ & $\pm \quad 0.153$ & $0.606 \pm$ & \pm 0.154 & 0.660 & \pm 0.171 \\
\hline \multicolumn{7}{|l|}{ Acetoacetate $(\mu \mathrm{mol} / \mathrm{l})$} \\
\hline Arterial & 331 & \pm 20 & 337 & \pm 22 & 339 & \pm 21 \\
\hline Hepatic venous & 385 & \pm 21 & 388 & \pm 20 & 391 & \pm 21 \\
\hline Hepatic venous - arterial & 53 & \pm 10 & 51 & \pm 10 & 52 & \pm 9 \\
\hline Splanchnic acetoacetate output $\mathrm{t}^{\mathrm{a}}\left(\mu \mathrm{mol} \cdot \mathrm{kg}^{-1} \cdot \min ^{-1}\right)$ & $0.219=$ & $\pm \quad 0.261$ & $0.218 \pm$ & $\pm \quad 0.231$ & 0.312 & \pm 0.138 \\
\hline
\end{tabular}

Results are expressed as mean \pm SEM

a Splanchnic output was calculated individually by the product of the hepatic venous - arterial concentration difference times the estimated hepatic blood flow for glucose, or the estimated hepatic plasma flow for IRI, C-peptide and metabolites and was expressed per kg body weight. Positive values of splanchnic output indicate net output, negative values net uptake

$\mathrm{b}$ Insulin production rate was estimated from splanchnic C-peptide output

NEFA $=$ non-esterified fatty acid

ing glucose ingestion was calculated as the area under the curve. Splanchnic glucose retention $\left(\mathrm{mg} \cdot \mathrm{kg}^{-1} \cdot 150 \mathrm{~min}^{-1}\right)$ was calculated as the amount of ingested glucose minus splanchnic glucose output above basal over $150 \mathrm{~min}$.

Splanchnic insulin and C-peptide output (pmol $\mathrm{kg}^{-1} \cdot$ time $^{-1}$ ) were determined as reported previously [16]. Insulin production rate was derived from splanchnic C-peptide output assuming an equimolar release of C-peptide and insulin by the B cell [24], and neglecting the minimal C-peptide retention by the liver [25]. Hepatic insulin retention was calculated as:
$100-\frac{[\mathrm{IRI}]_{\text {hepatic venous }} \times 100}{[\mathrm{IRI}]_{\text {anerial }}+\frac{\text { Insulin production rate }}{\text { Estimated hepatic plasma flow }}}$,

where IRI is given in $\mathrm{pmol} / 1$, insulin production rate in $\mathrm{pmol} / \mathrm{min}$, and estimated hepatic plasma flow in $1 / \mathrm{min}$.

All data are presented as mean \pm SEM unless otherwise indicated. The unpaired Student's t-test was used for statistical analysis. Coefficients of correlation and $95 \%$ prediction interval were determined by standard procedures [26]. 


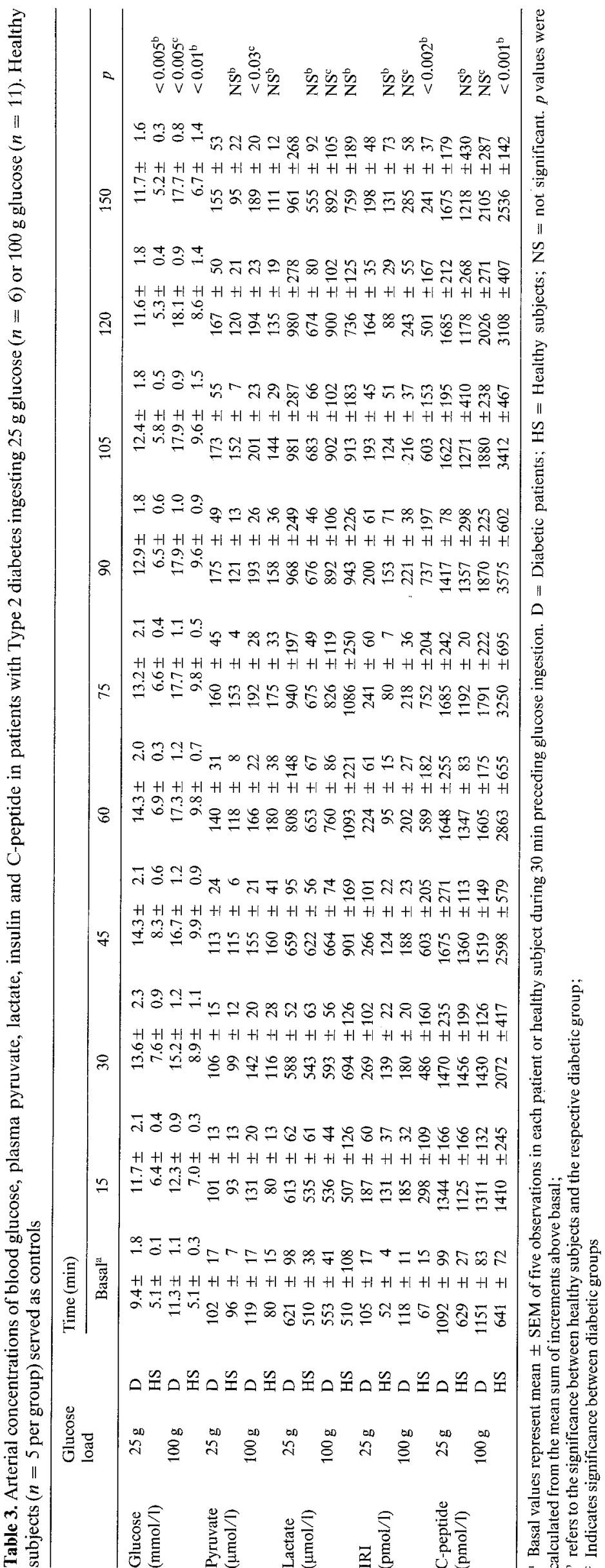

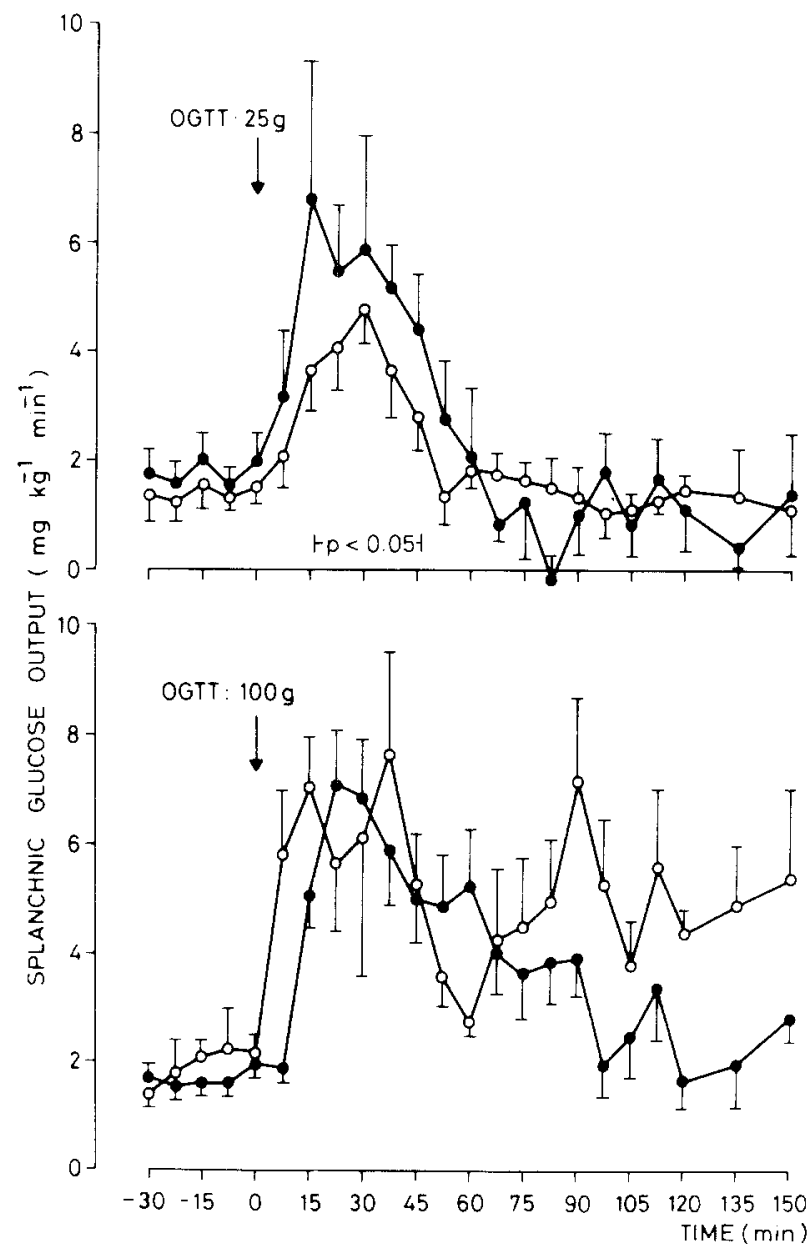

Fig. 1. Splanchnic glucose output in Type 2 diabetic patients $(\bullet)$ and healthy subjects $(O)$ after an oral glucose load (OGTT) of $25 \mathrm{~g}$ (upper panel;,$n=6 ; \bigcirc, n=5$ ) and $100 \mathrm{~g}$ (lower panel;,$n=11 ; \mathrm{O}, n=$ 5). $p$ values were calculated from the mean sum of increments above basal and indicate the significance of the difference in splanchnic glucose output following glucose ingestion from 15 to $45 \mathrm{~min}$ between healthy subjects and the diabetic group. Results are expressed as mean \pm SEM

\section{Results}

Arterial and hepatic venous concentrations and splanchnic exchange of substrates and hormones were studied for $30 \mathrm{~min}$ before glucose ingestion. Data given in Table 2 demonstrate that, during this period, arterial and hepatic venous values fluctuated to only a small extent. Arterial concentrations of substrates and hormones following the ingestion of glucose loads are listed in Table 3. It is apparent that arterial blood glucose levels rose in Type 2 diabetic patients by 52 and $62 \%$ following oral glucose loads of $25 \mathrm{~g}$ and $100 \mathrm{~g}$ respectively. The observed individual peak levels of arterial blood glucose were $14.9 \pm 2.2 \mathrm{mmol} / \mathrm{l}(25 \mathrm{~g})$ and $19.3 \pm 0.9 \mathrm{mmol} / 1$ $(100 \mathrm{~g})(p<0.025)$. Arterial blood glucose was by definition greater in the diabetic patients than in healthy subjects and stayed above basal levels in the diabetic patients until $150 \mathrm{~min}$. The typical spike-like pattern of glucose release from the splanchnic bed was observed [27]. The area under the curve of arterial blood glucose was 


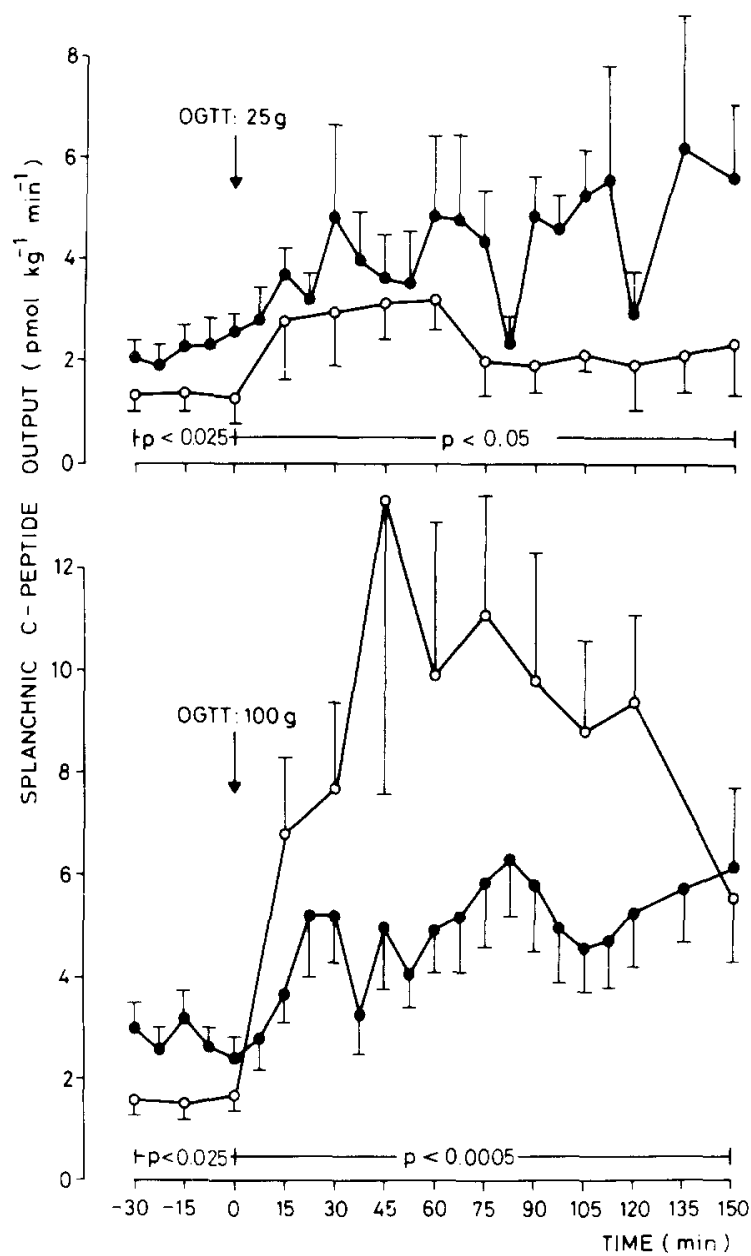

Fig. 2. Splanchnic C-peptide output in Type 2 diabetic patients (O) and healthy subjects $(O)$ before and after an oral glucose load (OGTT) of $25 \mathrm{~g}$ (upper panel;,$n=6 ; 0, n=5$ ) and $100 \mathrm{~g}$ (lower panel; $\mathbf{0}$, $n=11 ; 0, n=5$ ). $p$ values represent the significance of the difference of splanchnic C-peptide output before and following glucose ingestion between healthy subjects and the respective diabetic group. $p$ values after glucose loading were calculated from the mean sum of increments above basal. Results are expressed as mean \pm SEM

approximately twofold greater in the diabetic patients than in healthy subjects $(p<0.005$ for $25 \mathrm{~g}$ and $p<0.01$ for $100 \mathrm{~g}$ ). Arterial concentrations of pyruvate and lactate increased after glucose ingestion, the rise in plasma pyruvate being dose dependent $(p<0.03)$. No differences in the glucose-induced changes of plasma pyruvate and lactate were seen between healthy subjects and diabetic patients.

Basal arterial IRI and C-peptide concentrations in the diabetic groups were greater than those of healthy subjects. Arterial insulin showed a tendency to stay above normal in diabetic patients after a $25 \mathrm{~g}$ glucose load (IRI: $p<0.05$ at $60 \mathrm{~min}$ and $75 \mathrm{~min}$; C-peptide: $p<$ 0.05 at $75 \mathrm{~min}$ ), whereas an impaired rise in insulin and C-peptide levels was seen in the basally hyperinsulinaemic Type 2 diabetic patients compared with healthy subjects after $100 \mathrm{~g}$ glucose. Thus mean arterial IRI increased 2.6-fold after $25 \mathrm{~g}$, and 2.4-fold following $100 \mathrm{~g}$ glucose in the diabetic groups, compared with 2.9 -fold

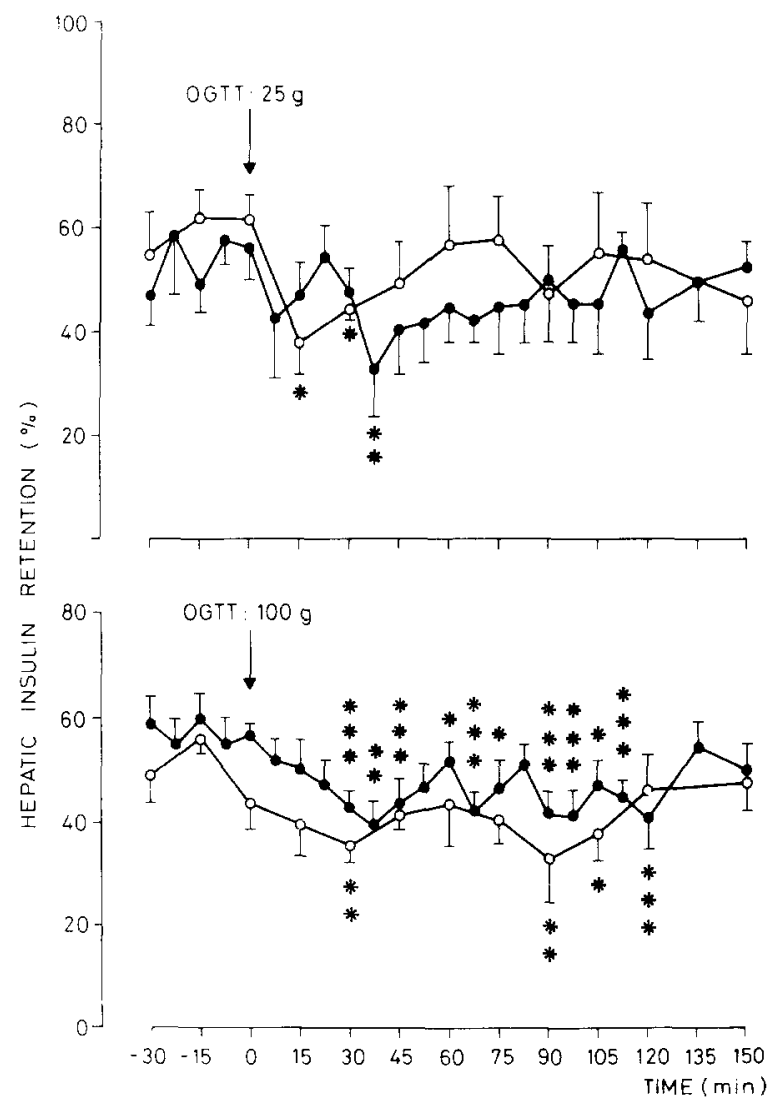

Fig.3. Hepatic insulin retention in Type 2 diabetic patients $(\bullet)$ and healthy subjects $(O)$ before and after an oral glucose load (OGTT) of $25 \mathrm{~g}$ (upper panel;,$n=6 ; \bigcirc, n=5$ ) and $100 \mathrm{~g}$ (lower panel;,$n=$ $11 ; 0, n=5$ ). Results are expressed as mean \pm SEM. $* p<0.05 ; * * p$ $<0.01 ; * * *<0.005$ indicate differences when compared with basal values

and ninefold increases respectively in healthy subjects. Serum C-peptide concentrations in the diabetic patients also rose immediately after glucose ingestion with peak levels about 1.7-fold ( $25 \mathrm{~g}$; normal 2.3-fold) and 1.9-fold $(100 \mathrm{~g}$; normal 5.6 -fold) above basal values. Mean peak values were observed at $75 \mathrm{~min}(25 \mathrm{~g})$ and at $150 \mathrm{~min}$ $(100 \mathrm{~g})$.

Estimated hepatic plasma flow (data not shown) increased within $15 \mathrm{~min}$ following glucose ingestion in the diabetic subjects and reached individual peak levels of $1,447 \pm 175 \mathrm{ml} / \mathrm{min}$ at $85 \mathrm{~min}(25 \mathrm{~g})$, and of $1,370 \pm$ $113 \mathrm{ml} / \mathrm{min}$ at $64 \mathrm{~min}(100 \mathrm{~g})$ (NS). No difference was seen between healthy subjects and diabetic patients in basal estimated hepatic plasma flow (normal subjects: $760 \pm 40 \mathrm{ml} / \mathrm{min}$; diabetic patients: $840 \pm 50 \mathrm{ml} / \mathrm{min}$ ).

Basal splanchnic glucose output for all diabetic patients was $1.78 \pm 0.16 \mathrm{mg} \cdot \mathrm{kg}^{-1} \cdot \mathrm{min}^{-1}$ (normal: 1.72 $\pm 0.15 \mathrm{mg} \cdot \mathrm{kg}^{-1} \cdot \mathrm{min}^{-1}$, NS), which rose fourfold to approximately $7 \mathrm{mg} \cdot \mathrm{kg}^{-1} \cdot \mathrm{min}^{-1}$ within $15-30 \mathrm{~min}$ in 
Table 4. Splanchnic glucose output, splanchnic retention of ingested glucose, splanchnic insulin output, and splanchnic C-peptide output per kg body weight over $150 \mathrm{~min}$ following oral glucose loading $(25$ and $100 \mathrm{~g}$ )

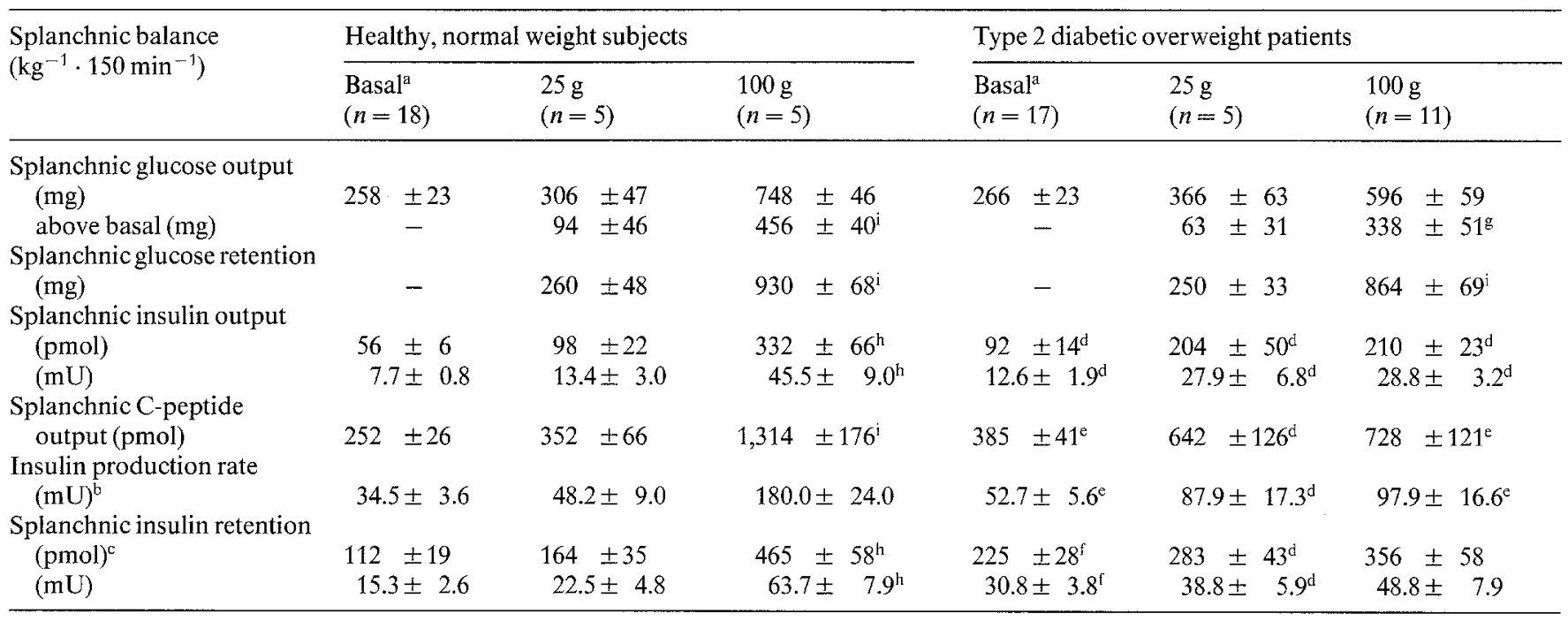

Results expressed as mean \pm SEM.

a Basal values were calculated for $150 \mathrm{~min}$ from the mean of five observations in each subject during 30 min preceding glucose loading

Insulin production rate $(1 \mathrm{mU}$ equalling $7.3 \mathrm{pmol})$ was estimated from total splanchnic C-peptide output.

c Splanchnic insulin retention was calculated by multiplying insulin production rate and hepatic insulin retention (\%).

${ }^{\mathrm{d}} p<0.05 ; \quad{ }^{\mathrm{e}} p<0.01 ; \quad{ }^{\mathrm{f}} p<0.005$ Significance of difference versus respective value of healthy subjects

g $p<0.01 ; \quad$ h $p<0.0025 ; \quad$ i $p<0.0005$ Significance of difference between ingestion of $100 \mathrm{~g}$ glucose and $25 \mathrm{~g}$ glucose

Table 5. Total splanchnic output of metabolites in the basal state and during $150 \mathrm{~min}$ following ingestion of $25 \mathrm{~g}$ and $100 \mathrm{~g}$ glucose

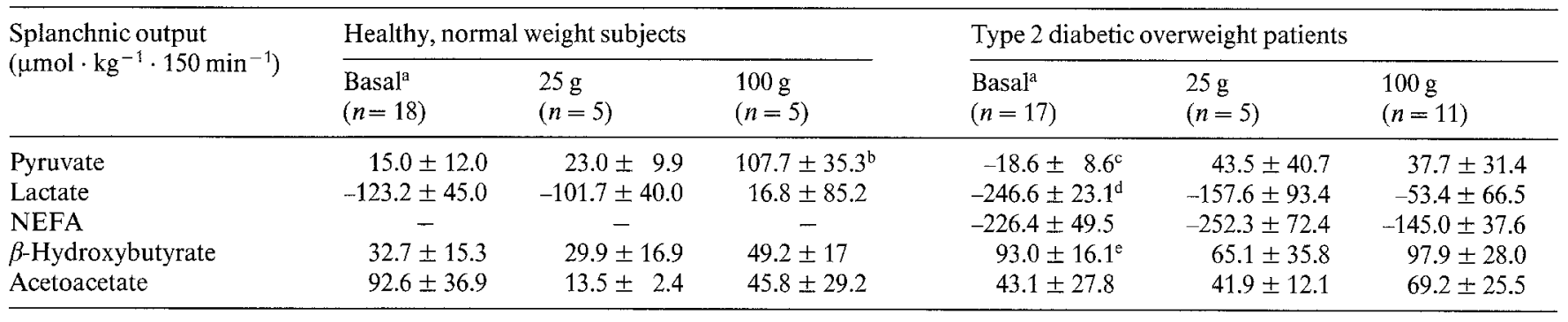

Values presented as mean \pm SEM.

a Basal values are extrapolated for a $150 \mathrm{~min}$ period from the mean of three observations during a 30 min basal period preceding glucose loading. NEFA $=$ non-esterified fatty acid

b $p<0.05$ when compared with values obtained after a 25 glucose load

${ }^{\mathrm{c}} p<0.025 ; \quad{ }^{\mathrm{d}} p<0.01 ; \quad{ }^{\mathrm{e}} p<0.005$ when compared with control values

the patients ingesting either $25 \mathrm{~g}$ or $100 \mathrm{~g}$ glucose (Fig. 1). This increase was transiently $(t=15-45 \mathrm{~min})$ greater in diabetic patients ingesting $25 \mathrm{~g}$ than the respective rise in normal control subjects $(p<0.05)$, but remained within the normal range in patients taking $100 \mathrm{~g}$ glucose. Splanchnic glucose output returned to basal values by 150 min only after ingestion of $25 \mathrm{~g}$. In contrast, increased rates of splanchnic glucose release following $100 \mathrm{~g}$ glucose were still seen at $150 \mathrm{~min}$ in healthy subjects, whereas splanchnic glucose output in the diabetic patients tended to approach baseline values after $2 \mathrm{~h}$.

Basal splanchnic C-peptide output for all diabetic patients $\left(2.57 \pm 0.28 \mathrm{pmol} \cdot \mathrm{kg}^{-1} \cdot \mathrm{min}^{-1}\right)$ was above normal $\left(1.68 \pm 0.17 \mathrm{pmol} \cdot \mathrm{kg}^{-1} \cdot \mathrm{min}^{-1} ; p<0.01\right)$. Splanchnic C-peptide output displayed considerable variability but stayed above normal in patients ingesting
25 g glucose $(p<0.05)$, whereas it was below normal from 45 to $120 \mathrm{~min}$ in diabetic patients ingesting $100 \mathrm{~g}$ glucose $(p<0.0005$; Fig. 2$)$.

The effects of oral glucose loading on cumulative splanchnic output of glucose, insulin and C-peptide and on the splanchnic retention of glucose and insulin are shown in Table 4. In both groups estimated basal splanchnic glucose output was in the same range, and rose following ingestion of $25 \mathrm{~g}$ and $100 \mathrm{~g}$ glucose by a slightly, but not significantly, greater increment in healthy subjects than in the obese diabetic patients. Total splanchnic glucose output reflected the same pattern in normal subjects [ $25 \mathrm{~g}: 21.5 \pm 2.8 \mathrm{~g} / 150 \mathrm{~min} ; 100 \mathrm{~g}: 55.8$ $\pm 4.7 \mathrm{~g} / 150 \mathrm{~min}]$ and the diabetic patients $[25 \mathrm{~g}: 28.8 \pm$ $4.3 \mathrm{~g} / 150 \mathrm{~min}(\mathrm{NS}) ; 100 \mathrm{~g}: 49.4 \pm 5.7 \mathrm{~g} / 150 \mathrm{~min}(\mathrm{NS})]$. Conversely, net splanchnic glucose retention increas- 
ed in the diabetic patients from $250 \pm 33 \mathrm{mg}$ $\cdot \mathrm{kg}^{-1} \cdot 150 \mathrm{~min}^{-1}$ after $25 \mathrm{~g}$ to $864 \pm 69 \mathrm{mg} \cdot \mathrm{kg}^{-1}$ $.150 \mathrm{~min}^{-1}(p<0.0005)$ after $100 \mathrm{~g}$ of glucose, again within the normal range.

Basal splanchnic IRI output in the diabetic patients was $0.61 \pm 0.09 \mathrm{pmol} \cdot \mathrm{kg}^{-1} \cdot \mathrm{min}^{-1}$, greater than in healthy control subjects $(0.37 \pm 0.04$ pmol $\cdot \mathrm{kg}^{-1} \cdot \min ^{-1} ; p<0.05$ ). Splanchnic insulin output remained above normal values in the diabetic patients after ingestion of $25 \mathrm{~g}$ glucose $(p<0.05)$, but was below normal after $100 \mathrm{~g}$ of glucose. Similarly, basal splanchnic C-peptide output in the diabetic patients was greater than that of the healthy subjects $(2.57 \pm 0.28$ versus 1.68 $\left.\pm 0.17 \mathrm{pmol} \cdot \mathrm{kg}^{-1} \cdot \min ^{-1} ; p<0.01\right)$. Relatively high levels of C-peptide persisted after a glucose load of $25 \mathrm{~g}$ $(p<0.05)$, while C-peptide release following $100 \mathrm{~g}$ of glucose was below the normal range $(p<0.01)$. Calculation of insulin production rate from splanchnic C-peptide output showed a basal rate in the diabetic patients of $0.35 \pm 0.04 \mathrm{mU} \cdot \mathrm{kg}^{-1} \cdot \mathrm{min}^{-1}$, above that of healthy control subjects $\left(0.23 \pm 0.02 \mathrm{mU} \cdot \mathrm{kg}^{-1} \cdot \mathrm{min}^{-1} ; p<\right.$ 0.01 ). Insulin production rate following glucose ingestion rose in a dose-dependent manner both in diabetic patients and healthy subjects. However, hyperinsulinaemia was only maintained in the diabetic patients after $25 \mathrm{~g}$ of glucose and fell below normal when $100 \mathrm{~g}$ of glucose were ingested $(p<0.01)$. Splanchnic C-peptide output and arterial C-peptide concentration were closely related both in the diabetic patients $(r=0.64 ; p<0.01)$ and healthy control subjects $(r=0.75 ; p<0.001)$.

Calculated absolute splanchnic insulin retention (Table 4) in the basal state was greater in the diabetic patients than in healthy subjects $(p<0.005)$. Splanchnic insulin retention rose in the diabetic patients to $283 \pm 43$ $\mathrm{pmol} \cdot \mathrm{kg}^{-1} \cdot 150 \mathrm{~min}^{-1}$ after $25 \mathrm{~g}$ of oral glucose $(p<0.05$ versus normal), and to $356 \pm 58 \mathrm{pmol}$ $\cdot \mathrm{kg}^{-1} \cdot 150 \mathrm{~min}^{-1}$ (NS versus normal) with $100 \mathrm{~g}$ of glucose. The relative amount of insulin retained by the splanchnic bed in the diabetic patients was $54 \pm 3 \%$ during basal conditions, well within the normal range $(51 \pm$ $4 \%$ ). However, relative splanchnic insulin retention fell transiently by one-third following oral glucose loading both in healthy control subjects $(p<0.01)$ and in the diabetic patients $(p<0.005)$. This effect was more pronounced in the diabetic patients after ingestion of $100 \mathrm{~g}$ glucose (Fig. 3).

Splanchnic exchange of pyruvate, lactate, non-esterified fatty acids, $\beta$-hydroxybutyrate and acetoacetate in the basal state and following glucose loading are shown in Table 5. Basal uptake of pyruvate $(p<0.025)$ and lactate $(p<0.01)$ as well as output of $\beta$-hydroxybutyrate $(p$ $<0.005$ ) were greater in the diabetic patients than in healthy subjects. Following glucose ingestion splanchnic uptake of lactate decreased and pyruvate uptake reverted to a net output. This pattern of splanchnic balance of metabolites did not differ from that seen in control subjects. No change in splanchnic output of $\beta$-hydroxybutyrate and acetoacetate occurred in the diabetic pa- tients after an oral glucose load. Splanchnic output of total ketone bodies in Type 2 diabetes (calculated as the sum of $\beta$-hydroxybutyrate and acetoacetate) correlated well with the amount of non-esterified fatty acid uptake in the basal state $(r=0.809, p<0.01)$ but not after glucose ingestion.

\section{Discussion}

In this study the hepatic venous catheter technique was used in obese hyperinsulinaemic Type 2 diabetic patients to extend previous observations in healthy man $[16,17]$ on the response of splanchnic glucose and metabolite exchange to glucose ingestion as well as that of insulin and C-peptide release. Specifically, the experiments were designed to investigate, in overweight Type 2 diabetic patients with peripheral basal hyperinsulinaemia, the fate of insulin across the splanchnic bed, and to determine the escape of both glucose and metabolites from the splanchnic area after ingestion of different amounts of glucose. Of particular interest was the difference between the two groups with respect to the interrelationship of insulin production rate and splanchnic glucose retention after oral glucose loading. As all Type 2 diabetic patients were markedly different in age and weight from the control group, all data were expressed per $\mathrm{kg}$ body weight.

Excessive serum insulin response has been seen in both Type 2 diabetes [28] and obesity [29,30], and fasting hyperinsulinaemia has been described in obese as well as in non-obese patients with impaired glucose tolerance [29]. However, others have found normal [31, 32] or low $[1,33]$ serum insulin concentrations in Type 2 diabetes. These differing observations may reflect aetiopathogenic heterogeneity of Type 2 diabetes, part of which may be explained on the basis of insulin resistance $[10,28]$. To elucidate these discrepancies further measurement of pancreatic insulin release is mandatory. Such direct measurements of insulin release became feasible by means of the hepatic venous catheter technique only after it had been shown that the pancreatic B cell releases $C$ peptide and insulin in equimolar quantities [24]. The insulin production rate can thus be calculated if it is assumed that $\mathrm{C}$-peptide is not extracted to any significant extent by the liver [25]. Our studies using this concept showed a basal insulin production rate in obese hyperinsulinaemic Type 2 diabetic patients which was 1.5 times that reported in healthy man [16]. This elevation persisted after administration of a small glucose load ( $25 \mathrm{~g})$, but not when $100 \mathrm{~g}$ of glucose were ingested. In the latter situation, the post-prandial insulin production rate was in the low normal range with a slightly delayed rise following glucose ingestion (Fig. 2). Calculating the increment in insulin output following a $100 \mathrm{~g}$ glucose load, it is apparent that Type 2 diabetic patients had less of an increment in insulin output than the normal subjects. These findings confirm observations indicating a diminished 


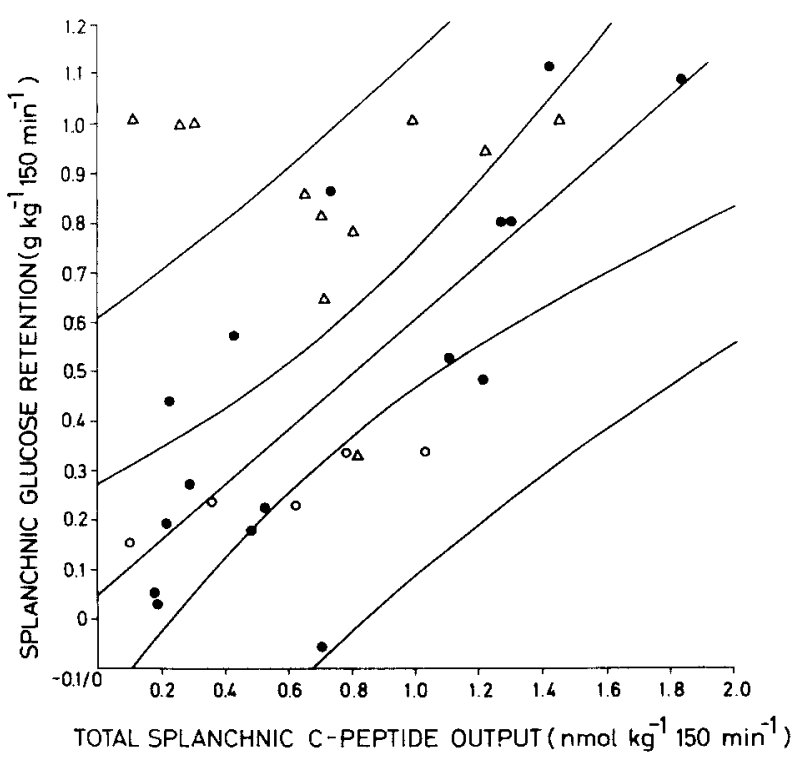

Fig.4. Relationship between splanchnic glucose retention and total splanchnic C-peptide in healthy control subjects $(\bullet, n=16)$ and in obese Type 2 diabetic patients ingesting either $25 \mathrm{~g}(\mathrm{O}, n=5)$ or $100 \mathrm{~g}$ $(\triangle, n=11$ ) of glucose. Solid lines indicate regression (midline), \pm SEM (hyperbolic curves) and 95\% (outer lines) prediction interval for the correlation of splanchnic glucose retention and splanchnic C-peptide output in normal control subjects

insulin response to glucose ingestion in maturity-onset Type 2 diabetes $[2,34]$. The change of absolute basal and stimulated hyperinsulinaemia to low-normal insulin release following $100 \mathrm{~g}$ of oral glucose (Fig. 2) suggests that the $\mathrm{B}$ cell in hyperinsulinaemic Type 2 diabetes can compensate for a small amount of ingested substrate, but not for an excessive oral glucose load, implying exhaustible insulin release. This relates well to data reported by Stern et al. [35], demonstrating that the insulin delivery rate in Type 2 diabetes tends to correspond directly to plasma glucose concentration unless severe degrees of hyperglycaemia prevail. These findings also agree with the clinical experience that diabetic patients should ingest multiple small meals in the course of the day, rather than a few large meals.

Relative insulin trapping by the splanchnic bed in this study was $54 \pm 3 \%$ in the basal state for diabetic patients, not significantly different from the $51 \pm 4 \%$ observed in normal control subjects. As the latter value also accounted for recirculating insulin, it was lower than that reported previously [16]. Although the estimate of hepatic insulin extraction obtained is somewhat greater than the $43.7 \pm 2.7 \%$ observed in the dog, it is still within the range of $7 \%-74 \%$ reported experimentally [36]. The transient fall in relative splanchnic insulin extraction following glucose ingestion in healthy man, and even more so in Type 2 diabetes after ingestion of $100 \mathrm{~g}$ glucose, is in keeping with decreased hepatic insulin extraction observed in Type 2 diabetes following IV isoproterenol [37], but is in contrast to the augmented hepatic insulin retention seen following intraduodenal glucose loading in the anaesthetized dog [38]. The latter discrepancy may be due either to lack of anaesthesia, to difference in species or to some difference in C-peptide binding by the liver in the overweight Type 2 diabetic patients. Increased trapping by the liver of C-peptide has been seen in a small number of obese pigs [39]; this explanation appears feasible as obese subjects possibly display a metabolic clearance of insulin $25 \%$ higher than that of normal subjects. This estimate of insulin clearance is however compromised by the disparate results obtained depending on the use of either radio-iodinated or unlabelled insulin [40].

It is apparent that the first site of action for any endogenous insulin is the liver. Insulin causes the splanchnic bed to retain $25 \%-85 \%$ of a given oral glucose load in healthy man $[16,27]$. In this study, overweight Type 2 diabetic patients showed a basal splanchnic glucose output of $1.78 \pm 0.16 \mathrm{mg} \cdot \mathrm{kg}^{-1} \cdot \mathrm{min}^{-1}(n=17)$ which was almost identieal to that of healthy control subjects $(1.72$ $\left.\pm 0.15 \mathrm{mg} \cdot \mathrm{kg}^{-1} \cdot \mathrm{min}^{-1}\right)$, confirming the findings of others $[12,13]$. Following glucose loading splanchnic glucose output rose in the diabetic patients transiently above normal values when $25 \mathrm{~g}$ (Fig.1), but not when $100 \mathrm{~g}$ glucose were ingested. Cumulative splanchnic glucose output for both groups (per $\mathrm{kg}$ over $150 \mathrm{~min}$ ) was however identical with that of healthy controls. These findings are in part at variance with those of Felig et al. [13] who reported on seven non-obese but hyperinsulinaemic Type 2 diabetic patients whose total splanchnic glucose output was normal in the basal state, but increased beyond normal values after $100 \mathrm{~g}$ of oral glucose. Net splanchnic glucose production in the normal range has also been observed in insulin-dependent diabetic patients while off insulin with only mild glycosuria [41]. Unfortunately, no hepatic venous C-peptide or insulin concentrations are available for any of these patients. It may well be that the observed differences are due to the small number of patients studied and to the wide range in blood glucose values, or to methodological difficulties in the measurement of minute differences in hepatic-venous and arterial blood glucose concentrations. The normal post-prandial splanchnic glucose output (above basal) in the presence of an increased insulin production rate, as found in our patients after $25 \mathrm{~g}$ of oral glucose (Table 4), probably indicates compensated hepatic insulin resistance. However, these data may also be explained by the assumption of an insulin response exceeding physiological requirements for optimal glucose retention. In the case of the $100 \mathrm{~g}$ glucose load, however, reduced insulin production rate and normal splanchnic glucose output suggest autoregulation by hyperglycaemia of hepatic glucose retention [42]. Post-prandial hyperglycaemia would thus be the result of impaired peripheral glucose utilization. Modulation of hepatic glucose output by hyperglycaemia as described previously [43] has also been supported by experiments in vitro [44], demonstrating a permissive effect of insulin on the autoregulation of glucose balance by maintaining the ratelimiting enzymes [45]. Thus it is feasible that suppression of net splanchnic glucose production by hyperglycae- 
mia, as observed in intact man [46], also contributes in Type 2 diabetes in keeping splanchnic glucose output in or near the normal range even in the presence of hepatic insulin resistance. Increasing hyperglycaemia may also explain why splanchnic glucose output declines with time in Type 2 diabetes after a $100 \mathrm{~g}$ glucose load. Alternatively, seemingly 'normal' splanchnic glucose output and lower insulin response to glucose ingestion could also be due to incomplete glucose absorption from the gut as gastric emptying time may be delayed in diabetic patients [47].

Comparing splanchnic glucose retention and total splanchnic C-peptide output after an oral glucose load in healthy control subjects and in the diabetic patients (Fig.4), it is apparent that all but three patients had values within the normal range. In these three patients, the association of decreased total splanchnic C-peptide output with seemingly increased splanchnic glucose retention may indicate incomplete absorption of glucose within the observation period, possibly due to delayed stomach emptying from diabetic gastroenteropathy [47]. The predominantly normal relation of splanchnic glucose retention and insulin production rate again suggests that the majority of the obese Type 2 diabetic patients with basal hyperinsulinaemia studied had impaired peripheral rather than hepatic glucose utilization as the main cause of post-prandial hyperglycaemia, and that the homeostatic function of the liver was retained [48]. Predominance of peripheral insulin resistance in our diabetic patients is also strengthened by the association of a twofold rise in arterial blood glucose concentration (as estimated by the area under the curve) and normal splanchnic glucose output following glucose ingestion. Part of the peripheral insulin resistance in our diabetic patients with basal hyperinsulinaemia may be due to an age-related impairment of tissue sensitivity in elderly patients with decreased glucose tolerance, but normal suppression by insulin of hepatic glucose production [49]. Furthermore, obesity per se can contribute to peripheral insulin resistance by decreasing the ability of insulin to promote glucose uptake by muscle and adipose tissue in overweight patients $[50,51]$. In this context, it must also be emphasized that the observed close relationship between insulin secretion and hepatic glucose retention in healthy man and Type 2 diabetic patients does not prove a causally-related event. Mechanisms other than insulin, such as portal hyperglycaemia, may be the major factor explaining 'normal' hepatic glucose retention in our patients.

Besides these observations on glucose, insulin and Cpeptide, the present study also describes the splanchnic exchange of substrates (pyruvate, lactate, non-esterified fatty acids, $\beta$-hydroxybutyrate and acetoacetate) before and following glucose ingestion. These data demonstrate an increased splanchnic uptake of the gluconeogenic substrates pyruvate and lactate in obese hyperinsulinaemic Type 2 diabetic patients, and an augmented output of $\beta$-hydroxybutyrate in the basal state. However, after an oral glucose load, the pattern of splanchnic substrate exchange was similar in the diabetic patients and in healthy controls. The observed increased uptake of gluconeogenic precursors but elevated splanchnic output of $\beta$-hydroxybutyrate appears to reflect the degree of insulin deficiency in a diabetic state $[13,52,53]$. However, since basal hyperinsulinaemia prevailed in our patients, these data are consistent with insulin resistance of the liver as far as gluconeogenic substrates and ketones are concerned. Similarly, increased uptake of glucose precursors due to hepatic resistance to insulin has been described for obese non-diabetic patients [54].

We conclude from these observations in overweight Type 2 diabetic patients with basal hyperinsulinaemia that (1) increased insulin release perists after a small glucose load $(25 \mathrm{~g})$, possibly compensating for hepatic insulin resistance, but is impaired when a large oral glucose load (100 g) is ingested; (2) relative splanchnic insulin retention is transiently decreased in obese Type 2 diabetic patients and less so in healthy controls following a large glucose load, probably due to impaired hepatic trapping of insulin; and (3) splanchnic glucose output is within the normal range both in the basal state and after glucose ingestion. These data suggest that obese patients with hyperinsulinaemic Type 2 diabetes represent a subgroup of diabetic patients with predominant peripheral, and less so hepatic, insulin resistance, this being responsible for post-prandial hyperglycaemia which is associated with a compensating but exhaustible increase in insulin production rate.

Acknowledgements. We thank Dr. K. Kletter for statistical advice. The technical assistance of Mrs. A. Hofer, Mrs. E. Nowotny, Ms. B. Neuhuber, Mrs. L. Geier, and Mrs. H. Haslinger is greatly appreciated. This study was supported by grant No.3875 of the 'Fonds zur Förderung der wissenschaftlichen Forschung Österreichs'. Part of the data have been reported previously at the 16th Annual Meeting of the European Association for the Study of Diabetes, Athens, Greece, 24-27 September, 1980

\section{References}

1. Perley MJ, Kipnis DM (1967) Plasma insulin responses to oral and intravenous glucose: studies in normal and diabetic subjects. J Clin Invest 46:1954-1962

2. Bagdade JA, Bierman EL, Porte D (1967) The significance of basal insulin levels in the evaluation of the insulin response to glucose in diabetic and non diabetic subjects. J Clin Invest 46:1549-1557

3. Yalow RS, Berson SA (1960) Plasma insulin concentrations in nondiabetic and early diabetic subjects. Diabetes $9: 254-260$

4. Reaven G, Miller R (1968) Study of interrelationship between glucose and insulin responses to an oral glucose load in man. Diabetes $17: 560-569$

5. Tchobroutsky G, Kopf A, Eschwege E, Assan R (1973) Serial postprandial plasma insulin levels in subjects with and without diabetes. Diabetes 22:825-833

6. Fajans SS, Floyd JC Jr, Taylor EC, Pek S (1975) Heterogeneity of insulin responses in latent diabetes. Trans Assoc Am Physicians 87: 83-94

7. Harano Y, Hidaka H, Takatsuki K, Ohgaku S, Haneda M, Moti S, Kawagoe K, Shigata Y, Abe H (1978) Glucose, insulin, and somatostatin infusion for the determination of insulin sensitivity in vivo. Metabolism 27: 1449-1452 
8. Shen SW, Reaven GM, Farquhar JW (1970) Comparison of impedance to insulin-mediated glucose uptake in normal subjects and in subjects with latent diabetes. J Clin Invest 49: 2151-2160

9. DeFronzo R, Deibert D, Hendler R, Felig P, Soman V (1979) Insulin sensitivity and insulin binding to monocytes in maturity onset diabetes. J Clin Invest 63:939-946

10. Reaven GM, Olefsky JM (1978) The role of insulin resistance in the pathogenesis of diabetes mellitus. Adv Metab Disord 9:313-331

11. Himsworth $H$ (1949) The syndrome of diabetes mellitus and its causes. Lancet 1: 465-472

12. Bearn AG, Billing BH, Sherlock S (1951) Hepatic glucose output and hepatic insulin sensitivity in diabetes mellitus. Lancet 2 : 698-701

13. Felig P, Wahren J, Hendler R(1978) Influence of maturity onset diabetes on splanchnic glucose balance after oral glucose ingestion. Diabetes 27:121-126

14. Shreeve WW, Baker N, Miller M, Shipley RA, Incefy GE, Craig JW (1956) $\mathrm{C}^{14}$ studies in carbohydrate metabolism. II. The oxidation of glucose in diabetic human subjects. Metabolism $5: 22-34$

15. Manougian E, Pollycove M, Linfoot JA, Lawrence JH (1964) $\mathrm{C}^{14}$ glucose kinetic studies in normal, diabetic and acromegalic subjects. J Nucl Med 5: 763-795

16. Waldhäusl W, Bratusch-Marrain P, Gasić S, Korn A, Nowotny P (1979) Insulin production rate following glucose ingestion estimated by splanchnic C-peptide output in normal man. Diabetologia $17: 221-227$

17. Bratusch-Marrain P, Waldhäusl W, Gasić S, Korn A, Nowotny P (1980) Oral glucose tolerance test: Effect of different glucose loads on splanchnic carbohydrate and substrate metabolism in healthy man. Metabolism 29:289-295

18. Bratusch-Marrain P, Björkman $\mathrm{O}$, Hagenfeldt L, Waldhäusl W, Wahren J (1979) Influence of arginine on splanchnic glucose metabolism in man. Diabetes 28:126-131

19. Felig P, Wahren J (1971) Influence of endogenous insulin secretion on splanchnic glucose and amino acid metabolism in man. $\mathrm{J}$ Clin Invest 50:1702-1711

20. Schmidt FH (1971) Methoden der Harn- und Blutzuckerbestimmung. In: Pfeiffer EF (ed) Handbook of diabetes mellitus, vol 2. Lehmanns, München, pp 913-946

21. Bergmeyer HU (ed) (1974) Methoden der enzymatischen Analyse. Weinheim Verlag Chemie

22. Waldhäusl, W, Bratusch-Marrain P, Dudczak R, Deutsch E (1977) The diabetogenic action of somatostatin in healthy subjects and maturity onset diabetes J Clin Endocrinol Metab 44: 876-883

23. Rowell LB, Blackmon JR, Bruce RA (1964) Indocyanine green clearance and estimated hepatic blood flow during mild to maximal exercise in upright man. J Clin Invest 43:1677-1690

24. Horwitz DL, Starr JI, Mako ME, Blackard WG, Rubenstein AH (1975) Proinsulin, insulin and C-peptide concentrations in human portal and peripheral blood. J Clin Invest 55:1278-1283

25. Stoll RW, Touber JL, Menahan LA, Williams RH (1970) Clearance of porcine insulin, proinsulin, and connecting peptide by the isolated rat liver. Proc Soc Exp Biol Med 133: 894-896

26. Statistik (1968) In: Dien K, Lentner C (eds), Dokumenta Geigy, 7th ed. Ciba-Geigy, Basel, pp 146-199

27. Felig P, Wahren J, Hendler R (1975) Influence of oral glucose ingestion on splanchnic glucose and gluconeogenic substrate metabolism in man. Diabetes 24: 468-475

28. Yalow RS, Berson SA (1960) Immunoassay of endogenous plasma insulin in man. J Clin Invest 39:1157-1175

29. Chiles R, Tzagournis M (1970) Excessive serum insulin response to oral glucose in obesity and mild diabetes. Study of 50 patients. Diabetes $19: 458-464$

30. Karam JH, Grodsky GM, Forsham PH (1963) Excessive insulin response to glucose in obese subjects as measured by immunochemical assay. Diabetes 12: 197-204

31. Karam JH, Grodsky GM, Pavlatos FC, Forsham PH (1965) Critical factors in excessive serum insulin response to glucose. Lancet 1: 286-289

32. Bornstein J, Lawrence DD (1951) Plasma insulin in human diabetes mellitus. Br Med J 2: 1541-1544
33. Fajans SS, Floyd JC Jr, Pek S, Conn JW (1969) The course of asymptomatic diabetes in young people. Clin Res 18:473

34. Pfeiffer EF, Ditschuneit H, Ziegler R (1961) Über die Bestimmung von Insulin im Blute am epididymalen Fettanhang der Ratte mit Hilfe markierter Glukose. IV. Die Dynamik der Insulinsekretion des Stoffwechselgesunden und des Altersdiabetikers nach wiederholter Belastung mit Glukose, Sulfonylharnstoffen und menschlichem Wachstumshormon. Ein Beitrag zur Pathogenese des menschlichen Altersdiabetes. Klin Wschr 39:415-426

35. Stern MP, Farquhar JW, Silvers A, Reaven GM (1968) Insulin delivery rate into plasma in normal and diabetic subjects. J Clin Invest 47: 1947-1957

36. Field JB (1972) Insulin extraction by the liver. In: Steiner DF, Freinkel N (eds) Handbook of physiology. American Society of Physiology, Washington D.C., Section 7, Volume 1: 505-513

37. Sando H, Lee YS, Iwamoto Y, Ikeuchi M, Kosaka K (1980) Isoproterenol-stimulated C-peptide and insulin secretion in diabetic and non-obese normal subjects: decreased hepatic extraction of insulin in diabetes. J Clin Endocrinol Metab 51:1143-1149

38. Field JB, Röjdmark S, Harding P, Chou MCY (1980) Role of liver in insulin physiology, Diabetes Care 3: 255-260

39. Kühl C, Faber OK, Hornnes P, Jensen JL (1978) C-peptide metabolism and the liver. Diabetes 27 (Suppl 1): 197-200

40. Genuth SM (1972) Metabolic clearance of insulin in man. Diabetes 21: $1003-1012$

41. Myers JD (1950) Net splanchnic glucose production in normal man and various disease states. J Clin Invest 29: 1421-1429

42. Liljenquist JE, Mueller GL, Cherrington AD, Perry JM, Rabinowitz D (1979) Hyperglycaemia per se (insulin and glucagon withdrawn) can inhibit hepatic glucose production in man. J Clin Endocrinol Metab 48: 171-175

43. Soskin S, Essex HE, Herrick JF, Mann FC (1938) The mechanism of the regulation of blood sugar by the liver. Am J Physiol 124: $558-567$

44. Hers HG (1976) The control of glycogen metabolism in liver. Ann Rev Biochem 45: 167-189

45. Davidson MB (1981) Autoregulation by glucose of hepatic glucose balance: Permissive effect of insulin. Metabolism 30:279-284

46. Rabinowitz D, Liljenquist JE (1978) Glucose metabolism in intact man: the responsiveness of splanchnic and peripheral tissue to insulin. Metabolism 27: 1832-1838

47. Domstad PA, Kim EE, Coupal JJ, Beihn R, Yonts S, Choy YC, Mandelstam P, DeLand FH (1980) Biologic gastric emptying time in diabetic patients, using Tc-99m-labeled resin-oatmeal with and without metoclopramide. J Nucl Med 21: 1098-1100

48. Forbath N, Hetenyi G Jr (1966) Glucose dynamics in normal subjects and diabetic patients before and after a glucose load. Diabetes $15: 778-789$

49. DeFronzo R (1979) Glucose intolerance and aging. Evidence for tissue insensitivity to insulin. Diabetes 28: 1095-1101

50. Rabinowitz D, Zierler KL (1962) Forearm metabolism in obesity and its response to intra-arterial insulin. J Clin Invest 41:2173-2181

51. Reaven GM, Olefsky JM (1978) Role of insulin resistance in the pathogenesis of hyperglycaemia. Adv Mod Nutr 2: 229-266

52. Wahren J, Felig P, Cerasi E, Luft R(1972) Splanchnic and peripheral glucose and amino acid metabolism in diabetes mellitus. J Clin Invest 51:1870-1878

53. McGarry JD, Foster DW (1977) Hormonal control of ketogenesis. Arch Int Med 137: 495-501

54. Felig P, Wahren J, Hendler R, Brundin T (1974) Splanchnic glucose and amino acid metabolism in obesity. J Clin Invest 53:582-590

Received: 22 April 1981

and in revised form: 23 February 1982

Professor W. Waldhäusl, M.D.

1. Medizinische Universitätsklinik

Division of Clinical Endocrinology and Diabetes Mellitus

Lazarettgasse 14

A-1090 Wien, Austria 